NBER WORKING PAPER SERIES

TAILSPOTTING: IDENTIFYING AND PROFITING FROM CEO VACATION TRIPS

David Yermack

Working Paper 17940

http://www.nber.org/papers/w17940

\author{
NATIONAL BUREAU OF ECONOMIC RESEARCH \\ 1050 Massachusetts Avenue \\ Cambridge, MA 02138 \\ March 2012
}

This paper previously circulated as "Tailspotting: How Disclosure, Stock Prices and Volatility Change When CEOs Fly to Their Vacation Homes." For helpful comments I thank Yakov Amihud, Sreedhar Bharath, Jonathan Cohn, Claudia Custodio, Ran Duchin, Robert Engle, Dan Galai, Marc Gabarro, William Greene, Peter Koudijs, Michael Knobler, Kate Litvak, Vikas Mehrotra, Lalitha Naveen, Ed Rice, Rik Sen, Denis Sosyura, Christopher Stanton, Nancy Su, Ralph Walkling, Wei Wang, an anonymous referee, and seminar participants at Adelaide, Alberta, Arizona State, Bocconi, Copenhagen, Frankfurt Center for Financial Studies, Hong Kong Polytechnic, LSU, Melbourne, Michigan, Norwegian School of Business, Oklahoma, Purdue, Queens University, Utah, University of Western Australia, Yale Law School, and the Drexel University Corporate Governance, Erasmus University Rotterdam Corporate Governance, and NYU-Penn Law and Finance conferences. Mark Maremont of The Wall Street Journal offered invaluable help with aircraft flight data, and Maria Aristizabal and Emiliya Schain provided superb research assistance. Part of this research was completed while I was a visiting professor at Erasmus University Rotterdam. The views expressed herein are those of the author and do not necessarily reflect the views of the National Bureau of Economic Research.

NBER working papers are circulated for discussion and comment purposes. They have not been peerreviewed or been subject to the review by the NBER Board of Directors that accompanies official NBER publications.

(C) 2012 by David Yermack. All rights reserved. Short sections of text, not to exceed two paragraphs, may be quoted without explicit permission provided that full credit, including $\mathbb{C}$ notice, is given to the source. 
Tailspotting: Identifying and profiting from CEO vacation trips

David Yermack

NBER Working Paper No. 17940

March 2012, Revised December 2013

JEL No. G14,G34

\begin{abstract}
$\underline{\text { ABSTRACT }}$
This paper shows close connections between CEOs' absences from headquarters and corporate news disclosures. I identify CEO absences by merging corporate jet flight histories with records of CEOs' property ownership near leisure destinations. I find that CEOs go to their vacation homes just after companies report favorable news, and CEOs return to headquarters right before subsequent news is released. When CEOs are away, companies announce less news than usual, mandatory disclosures are more likely to occur late, and stock prices exhibit sharply lower volatility. Volatility increases when CEOs return to work. CEOs spend fewer days out of the office when their ownership is high and when the weather is bad at their vacation homes.
\end{abstract}

David Yermack

Stern School of Business

New York University

44 West Fourth Street, Suite 9-160

New York, NY 10012

and NBER

dyermack@stern.nyu.edu 


\section{Tailspotting: \\ Identifying and profiting from CEO vacation trips}

\section{Introduction}

This paper documents a close connection between the timing of corporate news disclosures and CEOs' absences from headquarters. I identify CEO absences by merging publicly available flight histories of corporate jets with real estate records of CEOs' property ownership near leisure destinations. I find that CEOs go to their vacation homes just after companies report favorable news, and CEOs return to headquarters right before subsequent news is released. More good news is released when CEOs are back at work, and CEOs appear not to leave headquarters at all if a firm has adverse news to disclose. When CEOs are away from the office, stock prices behave quietly with sharply lower volatility. Volatility increases immediately when CEOs return to work. Mandatory Form 8-K disclosures of material company news are more likely to be filed late if news occurs while CEOs are at their vacation homes.

An example illustrating many of these patterns appears in Figure 1. On January 7, 2010, aerospace manufacturer Boeing Co. disclosed a $28 \%$ increase in annual commercial airliner deliveries and also issued an earnings forecast for the year ahead. Boeing stock rose 4\%, capping three days in which it outperformed the market by almost $10 \%$. The company's shares were quiet for the next several weeks, not moving significantly again until January 27, when Boeing 
announced strong quarterly earnings and its stock rose more than 7\%. In between these announcements, Boeing's CEO appears to have been at his vacation home, an inference based upon Federal Aviation Administration (FAA) records of company aircraft trips to and from an airport near his vacation residence in Hobe Sound, FL. During this period, the annualized volatility of Boeing's stock dropped to 0.16 , an unusually low level for a major blue chip. During the three days before and three days after his trip, the volatility was more than twice as high at 0.40 . I find patterns similar to Figure 1 for a sample of 217 trips to vacation homes lasting five work days or longer, taken by CEOs of 65 major U.S. companies during the four year period 2007-2010.

The paper's results seem consistent with an agency cost hypothesis, under which CEOs might slow down their firms' news disclosures for personal convenience on the days that they requisition company aircraft for golf or ski trips. However, the observed associations between news disclosures and vacation schedules may well be endogenous, if CEOs plan to be away from the office when the company expects to have little news to announce. To understand more clearly the direction of causation between disclosures and CEO absences, I conduct a variety of tests, examining how company news announcements change when CEOs return to headquarters at unexpected times. I also estimate a bivariate probit model of news days and vacation days, in which weather at the CEO's vacation site is used as an instrumental variable that should be associated with trips to the vacation home but not be connected to company news developments. Much of the analysis from these tests supports the agency interpretation, with news releases appearing to occurr less frequently simply because the $\mathrm{CEO}$ is absent from the office. However, it is difficult to test causation in the other direction, which would require an instrumental variable 
associated with news at headquarters but uncorrelated with the CEO's decision to take time off. A persuasive instrumental variable with these characteristics is hard to find. In addition, overall patterns of CEO vacations do not provide clear-cut support for the agency hypothesis. CEOs do not seem to over-consume leisure, as they spend about 17 work days a year at their vacation homes, in line with the schedules of typical mid-level managers. ${ }^{1}$ Many of their trips are short, and some appear to be interrupted for returns to headquarters when required.

A number of benign explanations also seem consistent with results in the paper. Some CEO responsibilities, such as secret merger negotiations, may require meetings at remote locations and put the CEO out of contact with headquarters or the news media. This "distance" hypothesis implies that corporate disclosure may be affected by the CEO's mere absence from headquarters, even for business trips, due to logistical complications. In principle one could test this conjecture by using business-related aircraft flights to identify the CEO's days away from headquarters and comparing news on those days with disclosures on vacation days. However, CEOs' business trips are hard to pinpoint, because we do not have passenger manifests for individual flights. Due to the difficulty of identifying a CEO's business flights, the paper does not have a benchmark for differentiating how company news disclosures change when the CEO leaves for vacation compared to routine trips away from headquarters for business.

A further "effort" hypothesis would suggest that companies disclose less news when the CEO is at his vacation home not because he is a great distance away, but merely because he is working less and producing less news. The effort hypothesis seems plausible since technology

\footnotetext{
${ }^{1}$ U.S. professional employees with 15 or more years service receive an average of 17 paid vacation days each year, according to a government study. See http://www.bls.gov/news.release/ebs.t05.htm.
} 
should allow most managers to communicate with headquarters from afar. This hypothesis is difficult to test directly, since we cannot observe the CEO's hour-to-hour activities at any location. Evidence that CEOs work less while at their vacation homes is circumstantial, based to their proximity to beaches, marinas, and ski resorts, as well as large perquisite disclosures for many of them of corporate aircraft use for personal reasons. ${ }^{2}$ However, the "effort" hypothesis is difficult to separate empirically from the "distance" hypothesis, and my inability to distinguish between them represents a limitation of the paper's research design.

This study illuminates a facet of corporate disclosure policy rarely noticed by investors or regulators. Since the 1930s U.S. authorities have established detailed regulations for the timing of company disclosures by enacting rules such as Regulation FD and the Sarbanes-Oxley Act (SOX). Since it became effective in 2003, SOX has required companies to report a wide range of material events on Form 8-K within either two or four business days. Notwithstanding these regulations, my results indicate systematic coordination between public news disclosures and the personal schedules of company CEOs.

The movements of company aircraft to and from CEOs' vacation residences provide very visible signals of pending news announcements and silences. With a trivial amount of research and monitoring, investors could observe flights of corporate aircraft in real time between the headquarters airport and CEOs' vacation locales, either by watching live FAA data on the

\footnotetext{
${ }^{2}$ Mandatory executive compensation disclosures indicate substantial leisure use of corporate aircraft use by nearly all the CEOs in the sample. In the case of Boeing, the company disclosed an incremental cost of $\$ 303,962$ for personal use of company aircraft in 2010 by its CEO, W. James McNerney Jr. Estimates on the Jet Tracker database put the incremental cost of a typical corporate aircraft flight in the neighborhood of $\$ 5,000$ to $\$ 10,000$ (depending on the plane model and distance flown), implying that Boeing's CEO took a fairly large number of personal trips on the company's executive jet in 2010. Conversations by the author with practitioners indicate that when preparing these disclosures, companies tend to classify a CEO's flight expenses as leisure-related only when necessary, for those trips on when he does no identifiable work.
} 
Internet or stationing scouts for "tailspotting" of the tail numbers of planes that land at leisure airports favored by CEOs such as Nantucket, Ma. or Naples, Fl. This information could support straightforward trading strategies, such as using derivatives to bet on declines in volatility when a CEO arrives at his vacation airport and increases in volatility when he departs. A similar pattern of volatility changes tied to the arrival of transport vessels is described by Koudijs (2013) in his historical account of British company shares trading on the Amsterdam exchange during the $18^{\text {th }}$ century. By merging the schedules of mail boats carrying news from England with daily share price changes in Amsterdam, Koudijs shows that volatility of stocks rose markedly when English ships docked in Amsterdam. In this study, the mechanism by which information reaches the market is somewhat different than in Koudijs's; whereas the mail boats in $18^{\text {th }}$ century Europe transported market-relevant news from abroad directly to investors, a $21^{\text {st }}$ century CEO's corporate jet seems to carry a gatekeeper who personally controls the release of news, and whose absence from headquarters implies silence by the firm.

The remainder of this paper is organized as follows. Section II presents a literature review connecting the results of this study to research in law, finance, and accounting. Section III describes the data collection and presents descriptive statistics about the sample. Section IV contains an analysis of stock returns and changes in volatility when a CEO is out of the office at his vacation home, as well as an analysis of corporate news releases. Section V concludes the paper.

\section{Literature review}

A large academic literature has investigated the strategic timing of news disclosure by 
corporations. These papers generally focus upon firms' attempts to influence analysts and journalists or exploit gaps in investors' attention. For instance, Patell and Wolfson (1982), Damodaran (1989), and many other studies find that firms release adverse news on late Friday afternoons, or in the evenings after the stock exchange has closed. Dye (2010) studies conditions under which companies will cluster or "bunch" several disclosures together in order to diminish the focus of investors upon any one announcement. Ahern and Sosyura (forthcoming) show that when negotiating stock-for-stock acquisitions, a bidder firm will often flood the news media with positive announcements, attempting to drive its share price higher and obtain a more favorable exchange ratio with the target firm.

Delaying or advancing news based upon the CEO's personal work schedule represents an additional aspect of disclosure policy that has not been previously noted by researchers. Numerous studies in the Management field have analyzed top managers' daily activities, though it is unusual for these papers to document direct associations between CEO schedules and companies' financial performance. One exception is Bandiera, Guiso, Prat, and Sadun (2011), who study one week of detailed work diaries for CEOs of 94 large Italian companies, tracking such variables as the number of hours worked and the frequency of meetings with colleagues and customers. The authors find a positive association between company productivity, measured as sales per employee, and hours worked by CEOs, especially for hours spent inside the firm rather than externally in meetings with outsiders such as investors or customers. Bennedsen, PérezGonzalez, and Wolfenzon (2012) study CEO illnesses and find a negative relation between CEO hospitalizations and subsequent company profitability. In both of these papers the outcome variables are reported at the annual level, in contrast to this study which looks more finely at 
daily stock price behavior when a CEO is in or away from the office.

Previous literature suggests that if a company were to alter its disclosure practices to accommodate absences of top managers, investors may react negatively over time. When a company delays or reduces its news disclosures, research indicates that a number of financial problems arise for the firm. Most of these studies rely on indexes of firms' disclosure quality created by analysts or other financial market professionals. These indexes evaluate firms according to the frequency, timeliness, and informativeness of their news announcements. According to this research, better corporate disclosure is associated with a lower cost of debt (Sengupta, 1998), greater liquidity for the firm's stock (Welker, 1995), increased willingness of institutional investors to hold a company's shares (Healy, Hutton, and Palepu, 1999; Bushee and Noe, 2000), and reduced litigation risk (Skinner, 1997). Leuz and Wysocki (2008) provide a recent survey of these studies.

This paper also extends a growing literature based upon CEOs' corporate jet usage. While early research such as Rajan and Wulf (2006) and Yermack (2006) focused upon connections between jet usage and company performance, this paper does not directly analyze the impact of jet flights. Instead, it employs data about CEOs' air travel as an identification strategy to identify their absences from headquarters. Two other recent working papers use The Wall Street Journal's Jet Tracker database, the same source employed in this study, to identify executive trips to specific locations. Bushee, Gerakos and Lee (2013) study executive trips to the "money center" cities of New York, Boston, Chicago, and San Francisco, where the managers are likely to be meeting with bankers, analysts, or investors. Lee, Lowry and Shu (2013) use aircraft travel records to compile data about the frequency of managers' trips from 
headquarters to company subsidiaries and other business locations.

\section{Data description}

Data for this study comes from the Jet Tracker online database made available for public search by The Wall Street Journal since May 2011 (Maremont and McGinty, 2011). The database, derived from FAA data, consists of "every private aircraft flight recorded in the FAA's air-traffic management system for the four years from 2007 through 2010," according to the newspaper. The database lists the tail number used to identify each aircraft, which the newspaper matches to individual companies using an FAA registry obtained with a Freedom of Information Act request as discussed below.

I search the Jet Tracker database for all companies included in the S\&P500 index between 2007 and 2010, using a list of companies and CEOs downloaded from ExecuComp. Approximately three-quarters of the S\&P500 appear in the database, with the frequency declining in relation to company size. If a company operates its own aircraft, the database rank-orders its 2007-2010 flights by airport. Invariably the headquarters city of the company is the first airport listed. For those companies whose aircraft fly often to airports serving leisure destinations such as Martha's Vineyard or Key Largo - which happens for perhaps half of all firms with planes - I search on-line real estate records available on Lexis-Nexis to determine whether the company's CEO owns property near that airport. ${ }^{3}$ This requirement of vacation property ownership causes a

\footnotetext{
${ }^{3}$ Searchable real estate databases include records of housing sales, property taxes, and mortgages and list the owner and exact address of properties across the United States. These data have been used by several recent papers such as Liu and Yermack (2012) and Cronqvist, Makhija, and Yonker (2012) to identify the main residences of corporate managers. To search these databases accurately, one must sometimes consult biographical sources to obtain information such as the CEO's middle initial or spouse's name. CEOs with common last names such as Smith or Johnson can be problematic, and in several such cases I excluded companies from the sample when I could not link an individual CEO to
} 
substantial reduction of the sample, as I am able to identify vacation homes owned by about onethird of those CEOs whose firms frequently operate aircraft to and from leisure destinations (many of the other CEOs may rent or stay at resort hotels, for instance, even if they visit the same destinations regularly). If I locate a property, I query the database for exact details of each flight to and from the vacation airport, on the assumption that those flights transport the CEO. I then use this flight information to construct a record of the CEO's trips to and from his vacation home.

Using the CEO's real estate ownership represents an identification strategy that allows me to infer, with high probability, that the CEO is actually a passenger on certain specific flights operated by his company's aircraft. Because it is far more difficult to know whether the CEO was aboard an aircraft that flew to a generic commercial destination, the paper lacks a benchmark to differentiate the effects of the CEO's business travel from his vacation trips.

Compiling flight records for individual trips requires some subjective judgment. Many companies' aircraft follow a pattern of flying from headquarters to a vacation destination, staying only a few minutes (presumably to discharge passengers), and then immediately returning to the headquarters airport or perhaps flying on to another city. This allows the plane to avoid local hangar fees near the CEO's vacation home and to undertake other corporate missions while the CEO is inactive. Some days later, a company aircraft will travel again to the CEO's vacation airport, stop briefly to pick up passengers, and then return once again to headquarters, so that CEO vacations often involve two separate round-trips by a company plane. Sometimes a CEO

specific real estate records with high confidence. On the advice of the staff of The Wall Street Journal, I excluded one company (Cintas Corp.) in which both the CEO and his father, the Chairman and predecessor CEO, had access to the company plane and each owned vacation property in the Florida Keys, making it impossible to infer which flights carried the CEO and which carried the father. 
appears to fly from his vacation airport to cities other than headquarters, often for an up-and-back trip in one day. Many of these side trips are to obvious leisure destinations, such as Napa, Ca., or Augusta., Ga., which many CEOs appear to visit for day trips of six hours or less, enough time for a tour of vineyards or a round of golf. If the CEO travels from his vacation home to another leisure destination, I count it as a continuation of the vacation trip, but if the trip appears to be to an urban or commercial destination, I treat it as the end of the vacation. If the corporate aircraft travels to the CEO's vacation airport but no return flight ever appears in the database, I do not include the trip in my sample; in these cases the CEO probably leaves by commercial air service or surface transport at a time I cannot identify. To classify a departure day from headquarters as either a work day or day away from the office, I use a cutoff of 4:00 p.m. takeoff, so if the CEO's plane leaves the headquarters city later than 4:00, I count the trip as having begun the next working day. For return days, if the flight lands in the headquarters city or another non-leisure destination at 12:00 noon or earlier, I count that as a work day.

These methods will obviously yield only an incomplete record of a CEO's vacation trips with some measurement error, since I will record trips to locations where he owns homes but not to other destinations where he may vacation without owning property. A few companies' planes travel regularly to Bermuda and Mexico resort towns and to Europe, but I do not have access to foreign real estate records to verify whether CEOs own property in these locations. On occasion CEOs may travel on commercial airlines or use time-sharing private jet services from an outside company such as NetJets, and I will miss these trips as well. Even when a CEO travels to his vacation home, he may spend time working on company business while there, so my measure of 
vacation travel may be overinclusive. ${ }^{4}$ I also cannot verify that CEOs are passengers on every flight made on company planes to the airports near their vacation homes; some of these trips may transport a CEO's family members or junior executives from the company, for instance.

My sampling procedure yields vacation schedules for 66 CEOs from 65 companies. I tabulate a binary vacation variable for each CEO each day, with the U.S. stock market calendar used to distinguish working days from weekends and holidays. For CEOs who hold their jobs continuously for the entire 2007-2010 period, the sample includes 1,008 days of data, an average of 252 stock market days per year. For CEOs who were appointed or resigned during this period, I tabulate daily vacation data only during their time in office, even though some seem to have access to their firms' planes while not serving in the CEO role. Table 1 presents basic overview statistics about the sample. In all, the database contains 51,426 company-days, of which 3,504, or $6.8 \%$, are spent by CEOs at their vacation homes, an average of about 17 work days per year. The data exhibit considerable variation across companies, with one CEO recording only three work days at his vacation home during the four-year, 1,008-day sample period, and another spending 197 days at his retreats during the same period.

Table 1 presents additional descriptive detail about CEOs' vacation trips. Generally these days out of the office follow unsurprising patterns, with Fridays and Mondays represented more than midweek days and a high concentration of absences from the office during July, August, and the winter holiday season. The frequency of CEO absences was higher in 2010 than 2007-09,

\footnotetext{
${ }^{4}$ An interesting recent case involves Houston company Nabors Industries Ltd. and its CEO Eugene Isenberg, who owns homes in Palm Beach and Martha's Vineyard, locations frequently visited by the company's aircraft. The CEO's employment contract entitles him to establish offices at any of his personal residences and to perform his work duties from those locations. In November 2011 the SEC opened an investigation because the company had disclosed zero expense for the CEO's personal use of company aircraft, apparently under a rationale that the CEOs' trips to these locations were always for business purposes. McGinty and Maremont (2011).
} 
perhaps because improved conditions in the national economy permitted CEOs to spend more time away from the office. In all, I identify a total of 1,150 distinct CEO vacation trips, uninterrupted by days back at headquarters, with lengths varying between one and 28 continuous work days. More than half of all CEO trips are just one or two days in length, but approximately $50 \%$ of all vacation days occur in trips at least one week (five working days) long, and I focus much of the analysis below on this subsample.

Table 2 presents a panel probit model of CEOs' decisions about when to spend days at their vacation homes. The binary dependent variable equals one if the CEO is at the vacation home on a weekday that the stock market is open. Explanatory variables include personal characteristics of each CEO, including age, percent ownership, and the log of total compensation (the TDC1 quantity reported by ExecuComp); net-of-market stock performance over the prior six months; variables about the weather at the vacation site and at headquarters; and indicator variables for each calendar month. ${ }^{5}$ I also include indicator variables for work days immediately preceding and immediately following public holidays. Each CEO is allocated a unique intercept term and standard errors are robust to serial correlation and heteroskedasticity. About 4 percent of the company-day observations drop out of regressions due to missing values for days that weather stations are off-line and do not report any data.

Estimates in Table 2 reveal a number of interesting patterns. CEO ownership and

\footnotetext{
${ }^{5}$ Daily weather data is available from the Internet portal of National Climatic Data Center of the U.S. National Oceanic and Atmospheric Administration (NOAA). I download the high temperature and depth of precipitation at the airport weather station closest to the CEO's vacation home for each day in the sample (most of these weather stations are at the commuter airports used by their aircraft), and I obtain the same information for the headquarters airport of each company. A small number of CEOs maintain pairs of leisure homes and visit them seasonally - for instance, Palm Beach in the winter and Martha's Vineyard in the summer. In these cases I use weather data for the winter location between October 1 and March 31, and the summer destination from April 1 through September 30 of each year.
} 
compensation both enter the model negatively with strong levels of significance, suggesting an incentive effect of CEOs spending less time away from the office when they have more personal wealth tied to performance. Older CEOs appear to take more vacation days than younger ones, an effect that may be somewhat endogenous, since more senior CEOs would not have survived in the job unless their firms were well managed. One variable that does not seem to matter is recent company performance: the company's net-of-market stock returns over the prior six months do not have a significant coefficient estimate. This conclusion does not change for alternative windows of past performance or if the variable is decomposed into separate company and market returns. CEOs are significantly more likely to take vacation days in proximity to public holidays when the stock market is closed.

Weather conditions at both the CEO's vacation home and at headquarters appear to be an important factor in choosing vacation days. Estimates in the second and third columns show that CEOs are less likely to spend a day at their vacation homes when the weather at the vacation site is rainy or cold, with opposite effects attributable to the weather at headquarters. Squared terms on the two temperature variables both have significant estimates with signs opposite linear terms, indicating that temperature-driven vacation patterns taper off and then reverse when heat or cold becomes extreme. The estimates on the linear and squared temperature terms in the second column indicate that CEOs are most likely to visit their vacation homes when the high daily temperature there is about $83^{\circ} \mathrm{F}$. In the third column, I test whether these effects vary for vacation homes near ski resorts in Colorado, Wyoming, Utah and Idaho. I interact the weather variables with an indicator that equals 1 for vacation homes in these locations between the months of October and March. All the weather patterns are reversed for ski locations: CEOs 
with ski lodges are more likely to take vacation days when it is snowing and when the temperature is colder (the estimates imply a local minimum of the likelihood function at $45^{\circ} \mathrm{F}$ but no local maximum; the function simply increases in value as the weather gets colder). When the ski variable equals zero, the estimates in the third column imply that the optimal temperature for a vacation day at a warm-weather location is $75^{\circ} \mathrm{F}$.

\section{Analysis}

In the sections below I analyze the impact of CEO absences from the office upon the daily performance of a company's stock. Section A has three subsections that document empirical relations between CEO absences and abnormal stock price behavior, changes in volatility, and patterns of corporate news announcements, respectively. Section B presents a range of tests useful for assessing the direction of causality between vacation trips and news announcements. These results appear in three subsections that examine news releases following vacation trips that are unexpectedly cut short, a bivariate probit model that jointly estimates the occurrence of news announcements and vacation trips, and analysis of firms' compliance with mandatory Form 8-K disclosure deadlines that are triggered when news occurs during CEO vacation trips. Section C discusses implications of the results for investors.

\section{A. Empirical Relations}

\section{i. $\quad$ Abnormal stock returns}

I investigate whether stock prices exhibit abnormal behavior around the days that the CEO is out of the office. Table 3 presents an analysis of abnormal stock returns in a standard 
four-factor Fama-French model, with indicator variables added to identify the days around CEO vacation trips. Standard errors are clustered at the company level. In column two, the estimate for an indicator for all CEO vacation days shows that stock returns are generally not different than normal on days that the $\mathrm{CEO}$ is absent from headquarters.

To increase the power of my statistical tests, I focus on long CEO vacations, which I define as those lasting five or more consecutive work days. If a CEO flies back to headquarters for one day and then returns to his vacation home, I count the one day as an "interruption" of a trip, with the additional spell of days treated as a continuation of the first trip. In all I identify 217 distinct long vacations by the 66 CEOs in the sample, which include 1,806 total work days away from the office, plus 36 interruption days, along with an uncounted number of weekend and holiday days. I do not include trips lasting four work days plus a weekday that is a stock market holiday, and I include interrupted trips only when there is a continuous stay of at least five days on either or both sides of the interruption. In the third column of Table 3, the vacation indicator is decomposed into pieces representing days of short and long trips, defined as those five or more working days in length. Again, the estimates for these variables seem uninteresting.

The most significant abnormal return estimates appear in columns four and five of Table 3, when the model includes indicators for the three-day periods immediately before and after the CEO leaves for a long trip of five or more work days. As shown in the table, abnormal stock returns are about 17 basis points higher than usual for each of the three days just before the CEO leaves the office, and about 20 basis points higher than usual for each of the three days after he returns. The latter window includes the CEO's second, third, and fourth days back in the office, during which the stock market would react to news disclosed at the close of the first three work 
days following the trip. Given the three-day length of these periods, the estimates correspond to appreciations in the company's stock of about $0.51 \%$ and $0.59 \%$, respectively, significant at the $5 \%$ and $1 \%$ levels, respectively. These patterns seem surprising, especially when the CEO returns to headquarters, since investors should be able to anticipate the pattern of returns and price them into stock prices in advance. This could be done by observing individual aircraft trips or becoming aware of those companies whose CEOs follow a regular vacation schedule every year (the short time series for this study - four years - precludes any robust identification of CEOs who have predictable schedules).

These estimates imply that companies release good news just before the CEO leaves for a long trip, disclose very little while he is gone, and finally announce more good news on his return. This interpretation is reinforced by the analyses of news releases and stock price volatility that appear below. Bad news announcements do not seem to occur in proximity to CEOs' longer trips away from the office. Since many CEOs begin or end vacations in the first month of the year, these data may have a plausible connection to the well-known "January effect" of stocks performing unusually well in the first weeks of a new year.

These findings are broadly consistent with recent papers by Tsiakas (2006, 2010), who studies abnormal stock returns around market holidays, which occur nine times each year during my sample period. Tsiakas finds positive expected returns both before and after mid-week holidays. For market holidays on Mondays or Fridays that represent part of a three-day weekend, abnormal returns are positive in advance of the long weekend, as found in my sample, but negative on the first day back to work. Inspection of my data shows that close to half of the lengthy CEO vacation trips are coordinated with holidays. Of the 217 individual trips in the 
sample, 31 begin at the start of a three-day holiday weekend or immediately prior to a mid-week holiday, and 35 trips end just after a holiday weekend or mid-week holiday. Many other trips include stock market holidays in the middle, so that a total of 107 out of 217 vacations coincide in some way with the holiday calendar.

\section{ii. Volatility}

Table 4 presents data about stock volatility when CEOs are at work, and when they are out of the office at their vacation homes. I calculate intra-day realized volatilities for the 65 companies in the sample, based on the standard deviation of stock returns calculated at fiveminute intervals using the method introduced by Andersen and Bollerslev (1997). At the top of Table 4, the data indicate significant drops in stock volatility when the CEO is at his vacation home: on these days, realized volatility is 0.307 , compared to 0.330 on all other days. In other words, volatility falls by about $10 \%$ when the CEO is out of the office, and the difference in the mean volatilities for these subgroups is significant below the $1 \%$ level.

The difference becomes even more dramatic when the CEO leaves for a long trip instead of a short one. Realized volatility during long CEO vacations, 0.287 , is about $13 \%$ below workday volatility. During short CEO trips of less than five days volatility also drops slightly below normal, to 0.328 , though this is not significantly less than the volatility on a work day. The volatility drop for long trips is more substantial, to 0.270 , when the period away includes a public holiday.

Changes in stock volatility around CEO vacations are economically large, similar to results in other studies that have examined important corporate events. Patell and Wolfson 
$(1979,1981)$ and a number of successor papers show significant increases in stock volatility on dates of earnings announcements, followed by immediate decreases the next day. While these studies concern changes in volatility around short news announcement windows, other papers have found sustained volatility changes after important events. For example, Ohlson and Penman (1985) find that volatility rises by approximately $30 \%$ following stock splits. Clayton, Hartzell and Rosenberg (2005) find that volatility increases by approximately $23 \%$ in the year following forced turnover of a CEO. That paper cites about 15 other studies than have found significant volatility changes after corporate events such as tender offers and dividend announcements.

Further detail in Table 4 show volatilities during periods around the start and end of long CEO trips. The data show that volatility gradually trends down in the three days before the CEO leaves, dropping more on his first day of trip, before bottoming out during the middle days of the trip. On the final day of a long trip, volatility is higher than before, and it rises further during the CEO's first three days back in the office.

The strong volatility patterns associated with CEO absences from headquarters might be endogenous, if CEOs cut short trips when the activity level at headquarters increases or are more likely to leave when the office is quiet. In general, CEOs' trips do not exhibit strong associations with certain days of the week or holidays that might be affected by market-wide changes in volatility. For instance, CEOs are most likely to be out of the office on Mondays and Fridays, according to data in Table 1. However, these two days have the highest, rather than lowest, market-wide volatility, an effect generally attributed to drops in liquidity that occur when traders leave for three-day weekends, taking either Friday or Monday off. See Kiymaz and Berument 
(2003). Tsiakas (2006) studies volatility around market holidays and finds an ambiguous pattern, with lower market volatility prior to mid-week holidays, higher volatility after long weekend holidays, and no significant effects in other cases.

My calculation of realized volatility on vacation days for all companies pooled together may be biased if CEOs from quieter companies with lower volatilities are away from the office more often than their counterparts from higher volatility companies, since CEOs in the first group would account for more observations in the sample. To examine this possibility, Table 5 shows the comparison between volatilities when the CEO is in the office and when he is away on a long trip, with the comparison statistics calculated separately for each of 49 companies (for the other companies in the sample, the CEO never is away for five or more consecutive days). As shown in Table 5, volatility is lower for the large majority of the 49 companies when the CEO is away on a long trip.

Data in Table 5 seem to provide some support for the effort hypothesis discussed above.. More news may be announced by firms when the CEO is at headquarters simply because he is directly involved in creating significant news events, by signing major contracts, meeting with regulators, deciding upon new strategies and the like. If this is the case, we would expect those firms whose CEOs take relatively little vacation time to respond most dramatically when the CEO is away. This is generally consistent with a pattern in the table that shows the largest volatility differentials occur for those firms whose CEOs take the fewest days off for long trips during the 2007-10 sample period. In contrast, for companies whose CEOs spend large amounts of time away, volatility seems to change little when they are absent, probably because they have developed a management style relying heavily upon delegation to subordinates. 


\section{iii. $\quad$ News announcements}

The patterns of stock price volatility described above are consistent with companies releasing news to the market just before the $\mathrm{CEO}$ leaves for a long trip, and $\mathrm{CEO}$ returning to the office just before the next major announcement by the firm. I test this possibility directly using daily news announcement data from the Thomson Reuters Significant Developments database, which the vendor describes as "a unique news analysis and filtering service providing a concise description of crucial, market-moving company news." This source consolidates major news affecting public companies from hundreds of worldwide sources and tabulates the date and time that information first becomes public. The database covers topics such as dividend announcements, mergers, earnings guidance, new product announcements, major contracts, regulatory decisions, and the like. I tabulate a binary variable that takes the value of one if the company makes a significant news announcement or an earnings announcement on each day in the sample. For announcements that occur after the 4:00 p.m. close of the stock market or over a weekend, I align them in the database with the next working day.

Studying news announcements in relation to CEO absences offers an advantage compared to investigating realized volatility, stock returns, or other market outcomes. When CEOs leave for vacation, many stock traders or analysts may also be out of the office, and volatility could change market-wide. Focusing only on a company's news disclosures allows the reader to evaluate directly the flow of raw material from a firm to its investors. If the news flow changes when a CEO is away, the result would help clarify the importance of the agency, distance, and effort hypotheses without any reference to how or when investors choose to act on the information they receive. 
Data in the third column of Table 4 show a pattern of news releases similar to that suggested by the analysis of realized volatilities discussed above and shown in the second column. On days that CEOs are in the office, companies announce earnings or significant news $13.3 \%$ of the time, a frequency that drops by about one-third to $9.6 \%$ when CEOs are away from the office. The effect is greater for longer trips, when the daily news announcement frequency drops to $8.3 \%$, compared to shorter trips, when it is $11.0 \%$. Differences in all of these numbers are statistically significant according to $t$-tests. The daily news announcement frequency tapers downward from $11.1 \%$ on the day before a CEO leaves for a long trip, to $9.2 \%$ on the first day away, then $8.2 \%$ on subsequent days in the middle of the trip, and finally $8.1 \%$ on the last day. It then shoots up to $14.3 \%$ on a CEO's first day back in the office. Longer trips that include public holidays have daily news frequencies of $7.8 \%$, below the frequency of $8.8 \%$ during longer trips that do not include public holidays.

Table 4's results showing declines in the frequency of company news announcements may seem surprising in the context of modern technology, since mobile phones, fax machines, and other innovations should permit top managers to stay in close contact with headquarters. To examine this conjecture, I study two subsamples of trips during which CEOs may face greater communication difficulties: ski vacations and trips to Hawaii. I assume that trips to Western ski resorts such as Aspen and Sun Valley, occurring between October and March, are associated with skiing. On these trips, CEOs may spend much of the workday on a mountain with limited cellphone coverage and no easy access to fax or video conference equipment. For Hawaii trips, the large difference in time zones compared to the continental United States may create difficulties in reaching the CEO and releasing timely news releases to the market. Data in Table 
4 support the hypothesis that when the CEO has especially limited access to communications technology, companies issue less news to investors. For ski trips, the daily frequency of material news falls to $6.8 \%$, much lower than the frequency of $9.6 \%$ for all vacation days, and for Hawaii trips (which are associated with just two firms in the sample), news disclosures almost stop completely, dropping to a daily frequency of $0.6 \%$.

While the data indicate fewer company news announcements when CEOs leave the office, the existence of a direct causal relationship at first seems ambiguous. CEOs may deliberately schedule vacations when they expect business to be quiet, as suggested by the data above indicating that nearly half of CEOs' long trips occur either adjacent to or overlapping a public holiday.

Attempting to understand the direction of causation between CEO vacations and news represents an important aspect of this study. If CEO vacations affect company news announcements, the results would imply an agency problem, with CEOs delaying news for personal convenience, undermining price discovery in the market. Alternatively, if CEOs modify vacation plans on account of news at headquarters, the results would suggest that CEOs make compromises in their work schedules for the sake of investor transparency. Ideal experiments to test these relations would involve suddenly forcing CEOs to take vacations and then observing their firms' disclosures, or randomly assigning material news to companies whose CEOs happened to be out of the office. Neither of these strategies is possible to implement in real life. Instead, I rely on two pieces of analysis to help identify the direction of causation, including (i) a comparison of news released when the CEO flies back from vacation at an unusual time, apparently for business reasons, with news released when the CEO flies back apparently due to 
poor weather at the vacation site; and (ii) bivariate probit models that estimate jointly the incidence of vacations and news releases, with the news and vacation variables modeled endogenously as a function of instrumental variables.

\section{B. The direction of causation}

The empirical results presented above might have very different implications depending upon the direction of causation between CEO absences and company news announcements. If companies delayed news announcements to accommodate CEOs' vacation schedules, the pattern would support an agency interpretation, but if CEOs scheduled their vacations during quiet news periods, the results would be consistent with a value-maximizing practice of CEOs absenting themselves from work at optimal times. To help identify the direction of causation, three types of analysis appear below. Subsection (i) examines news releases that occur when CEO vacation trips are cut short for business reasons and for weather reasons; the analysis compares the consequences of random variations in weather patterns with the consequences of random variations in business requirements. Subsection (ii) presents results from a bivariate probit model that estimates jointly the probability of vacation days and significant news days, with exogenous instrumental variables used to identify causation in each direction. Subsection (iii) examines firms' compliance with mandatory Form 8-K disclosure deadlines when news occurs during CEO vacation trips. If compliance is impacted during CEO absences, the results would be consistent with poor planning and an adverse tradeoff between CEO effort and disclosure.

i. $\quad$ Vacation trips cut short by business and by weather 
I create two subsamples of vacations that appear to end unexpectedly, one group apparently for business reasons, and the other apparently for weather reasons. If the company's release of news to the market depends upon the presence of the $\mathrm{CEO}$ at headquarters, we should observe similar frequencies of disclosure at the end of both subsamples of trips, although the news announced by the first group of firms should be materially more important than the disclosures by the second group.. The two subsamples attempt to emulate the ideal experiments of exogenously terminating trips (which should resemble vacations halted for bad weather) and exogenously delivering material information to a company (in the case of mid-week trip interruptions), although this emulation almost surely involves some degree of measurement error since some of the news disruptions and inclement weather events are likely foreseeable.

I identify business-related interruptions based upon the timing of flights back to headquarters. Minute-by-minute flight data indicate that CEOs rarely fly from their vacation homes back to headquarters on weekday mornings, except Mondays. Of the 1,150 individual vacation trips in the sample, only 42 , or $3.7 \%$, involve a return flight that arrives at the headquarters airport between 8:00 a.m. and 1:00 p.m. Tuesday through Friday (excluding two cases where the flight occurs on a holiday). I assume that these trips are likely to occur because of pressing business at headquarters that requires the executive to stop his vacation at an inconvenient time. The comparison sample involves rain-shortened vacations. This subsample includes 38 cases in which the CEO returns to headquarters on a Monday through Thursday, and the next day is a workday with at least $10 \mathrm{~mm}$. of precipitation at the vacation site. I assume that these trips are more likely to occur due to an adverse weather forecast than because of news at headquarters. Two events fall into both subsamples, so I delete them. 
In each subsample, news announcements increase despite the evident differences in motivations for the CEO's trips back to headquarters. When the CEO flies back apparently for business reasons, the company announces significant news that day $15.0 \%$ of the time, and on the following day, $12.5 \%$ per the time. When the CEO flies back apparently for weather reasons, the significant news disclosure frequencies are slightly higher, $15.7 \%$ on the day following the return day and $13.1 \%$ the next day. These news frequencies are modestly above those shown in Table 4 for CEOs' first two days back from long vacations, $14.3 \%$ and $11.0 \%$, respectively, and are also well above the $9.6 \%$ news frequency for CEO vacation days, though the differences are not statistically significant due to the small sample sizes of 40 and 38 trips, respectively. These data support an interpretation that news releases are tied to the CEO's presence at the office, rather than the converse. Although companies seem to announce more news simply because the CEO is back at work, disclosures connected to the business-related trips appear to be more material in the eyes of the market. The abnormal stock return over the first three days back is a significant $+0.45 \%$ for these 40 observations ( $t$-statistic 1.70 ), similar to the sample average reported above after the conclusions of CEOs' longer vacations. Intra-day volatility exhibits a day-over-day increase of 2.5 percentage points on the return day, increasing a further 1.4 percentage points the next day. The two-day increase in volatility has a significant $t$-statistic of 2.18. In the weatherrelated subsample, by contrast, the three-day abnormal stock return is a negative and insignificant $-0.53 \%$ ( $t$-statistic -1.32$)$ and intra-day volatility rises by only 0.8 percentage points and then 0.2 percentage for the first two days, with the two-day change not significant $(t$-statistic $=0.65)$.

A comparison of the actual news announced by companies in these two subsamples highlights differences in their importance, although the data must be interpreted with caution due 
to the small sample sizes. Among the set of CEOs with business-related vacation interruptions, eight announcements seem to have been especially noteworthy. Four of these disclosed significant merger and acquisition activity by their firms, including two cases of tactical moves in hostile takeover attempts, a successful completion of a tender offer, and government antitrust approval received for a very large acquisition (Comcast's merger with NBC-Universal). Another material announcement involved a company reducing its quarterly earnings guidance to analysts, and a further story announced a settlement with government authorities in a consumer safety investigation. Two quarterly earnings announcements also occurred. The remaining stories involved minor contract awards or joint venture announcements. In contrast, CEOs' vacations with weather-related disruptions were followed by news announcements of lower materiality, with only three of them appearing to have notable importance. One company disclosed the cancellation of an $\$ 800$ million government defense contract, one quarterly earnings release occurred, and in another case a company increased its earnings guidance. The remaining stories involved mostly minor contract awards, joint venture announcements, acquisitions of small private companies, two reiterations of earnings guidance, and a jury verdict against one firm for $\$ 47$ million that could not have been known at the time of the flight back to headquarters.

\section{ii. $\quad$ Bivariate probit analysis}

To investigate whether CEO absences from the office have a causal effect upon companies' news releases or vice versa, one must estimate joint models of CEO vacation trips and company news releases that treat either the vacation or news variable as endogenous. Because the two dependent variables of interest, company news releases and CEO vacation days, 
are binary $(0,1)$ variables, I cannot rely on standard simultaneous equations techniques such as two-stage least squares, and I instead use the bivariate probit model. Greene (1998) introduces the recursive bivariate probit as the most efficient estimator for a system of equations with binary dependent variables, in which one of the binary outcome variables also enters the equation of the counterpart variable as an explanatory on the right-hand side. ${ }^{6}$ It is not possible to model the endogeneity in both directions in the same system by placing each outcome variable on the righthand side of the counterpart equation, because such a model lacks statistical coherence and cannot be estimated.

Table 6, panel A, presents the bivariate probit estimates for the two-equation model of CEO vacation trips and company news releases, with the vacation variable modeled as endogenous using the six vacation site weather variables as instruments. As shown in Table 2, the weather (temperature and rainfall) at a CEO's vacation home has a strongly significant impact on a CEO's daily vacation decisions, and it seems implausible that the weather at a distant leisure location should have any connection to news developments at company headquarters. $^{7}$ Maximum likelihood estimation of the two-equation model proved difficult given the size of the dataset, and to achieve convergence I had to exclude the indicator variables for

\footnotetext{
${ }^{6}$ Greene shows that the bivariate probit approach has a simple, appealing and counterintuitive property, because it does not require the use of a fitted value of one variable in the model for the other as would be done in two-stage least squares. In the bivariate probit, the investigator can simply put either dependent variable on the right-hand side of the other equation, and the likelihood function for the joint model is structured in a way that accounts for the variable's underlying endogeneity. See Greene (1998, pp. 294-295). Recent applications in the finance literature include Naveen's (2006) bivariate probit model of CEO turnover in the presence of a endogenously designated "heir apparent" presumptive successor, and Jiang, Li and Wang's (2012) analysis of bankruptcy outcomes in the presence of endogenously determined activism by hedge funds.

${ }^{7}$ When the six vacation weather variables are included in a univariate probit model of company news releases, the two precipitation variables have estimates near zero with an insignificant likelihood ratio $\chi(2)$ test statistic of 1.12 for their joint significance. Some of the vacation site temperature variables do exhibit significant associations with news announcements made back at headquarters, but I can rely on the precipitation variables to identify the model.
} 
individual CEOs.

The model for news announcements includes, in addition to the endogenous CEO vacation variable, weather variables for the headquarters city, indicator variables for days of the week, indicators for individual months, and indicators for days immediately before or immediately after public holidays. I also include the company's difference in realized volatility compared to the prior day, with this difference lagged one day. This variable is used below in the estimation in Panel B before as an instrumental variable for significant news announcements. The news variable follows the definition in Table 4 and equals one for those days on which the company makes a quarterly earnings announcement or a significant news announcement, according to the Thomson Reuters Significant Developments database.

Estimates in Table 6, panel A, show that, even after accounting for the endogeneity of CEO vacation days, trips out of the office by the CEO appear to have a significantly negative relation with companies' daily decisions about whether to release news to investors. The estimated correlation of the residuals of the two equations, shown by the $\rho$ coefficient at the bottom of the table, is strongly positive and significant at 0.5035 , highlighting the need for the endogeneity correction. Other estimates in Table 6 closely follow intuition: news releases are more likely on Monday through Thursday as compared to Friday, while vacation days follow exactly the opposite pattern. News is less likely to be released and CEOs are more likely to be out of the office on work days that are adjacent to public holidays. Companies tend to announce news the day after a significant increase in realized volatility.

I reverse this analysis in panel B of Table 6, modeling the news variable as endogenous in order to investigate whether CEOs are more likely to be away from the office when significant 
news announcements are not expected. The one-day lagged difference in realized volatility serves as the instrumental variable for significant news announcements. While this variable exhibits the statistical properties required of an instrument, because of the nonlinear nature of the bivariate probit model no test exists for whether it meets the exclusion restriction. ${ }^{8}$ To justifying using the lagged change in realized volatility as an instrument requires a persuasive argument that the variable should be associated with expected news releases, which seems clear, but not with CEOs' decisions to leave for vacation, which is more uncertain. For the variable to be credibly unassociated with CEO absences, one would conjecture that top managers take little account of the intraday volatility of their share prices. In other words, if a company's shares closed unchanged in price from the prior day, the CEO would be indifferent to whether the stock behaved quietly or exhibited large swings during trading hours.

The recursive bivariate probit estimates in panel B do not support the hypothesis that CEO vacation trips occur endogenously based upon expectations of future news disclosures. The indicator variable for significant news days has an insignificant estimate in the vacation equation, even though the instrumental variable of the first difference in realized volatility has a strongly significant estimate. Unlike the estimates in panel A, the model in panel B exhibits very low estimated correlation of the residuals, 0.0180 , implying that the endogeneity correction may not be important. However, if the rationale for the instrumental variable presented above seems unpersuasive, the inconclusive results in panel B could be interpreted as the byproduct of a weak instrument.

\footnotetext{
${ }^{8}$ As shown in the table, this variable has a significantly positive association with subsequent news releases. Further investigation shows that it has close to zero correlation with the CEO vacation variable, and if it is included as a regressor in the probit model of CEO vacation days, it has an estimate near zero with an insignificant $p$-value of 0.78 . I am grateful to Nancy Su and Dan Galai for discussions that led to my choice of this instrument.
} 
As a robustness test of the interpretations from Table 6, I disaggregate the news announcements in the database according to whether the company controlled the timing of the disclosure, or whether the news was announced by an outside agent such as a competitor, regulator, or court of law. In the latter case, the company should have had little or no ability to anticipate the timing of the news, so that CEO absences should not be expected to exhibit significant associations with the news variable.

I partition the news observations by reading the headlines and synopses of the significant announcements used in the sample. The Thomson Reuters news database provides 7,722 individual items for my 65 companies during the sample period (this number does not include quarterly earnings announcements, which are obtained from a separate database, and it is not adjusted for the fact that companies sometimes make multiple announcements on the same day). I classify $16 \%$ of the news announcements as having been generated by external sources. The leading categories include government contract awards (522 items), regulatory decisions by government agencies (432 items), court rulings and jury verdicts (142 items) and lawsuits filed or threatened by competitors or plaintiffs' attorneys (133 items). Other externally created news items, much less numerous, include analyst rating changes, activism by major shareholders, and developments related to hostile takeover attempts.

Table 7 presents recursive bivariate probit estimates of the incidence of CEO vacation days and significant news announcements, with the news separated according to internal and external origin. For brevity, I tabulate estimates only for the key news and vacation dependent variables in each equation, but all regressions include the full range of explanatory variables used in Table 6. In the left column, the news variable equals one only for days in which significant 
news is generated internally by the firm itself, and I drop from the estimation all days with externally generated news (including a minor number of overlap days during which news occurs both internally and externally). In the right column, the news variable is defined in the opposite way, as it is set equal to one only for days with externally generated news, and observations are dropped for those days on which news is generated internally by the firm and also for overlap days. Estimates for the internal news model on the left of Table 7 are similar to those for the sample overall in Table 6; the vacation indicator variable has a negative and significant estimate in the news equation, while the news variable has only an insignificant variable in the vacation equation. In contrast, for the external news model on the right of Table 7, neither variable has a statistically significant estimate. This pattern of estimates is consistent with an interpretation that the timing of company news announcements are influenced by CEO absences, but only for news that is generated by the company itself, and not for news that is generated by external actors such as governments, courts, or competitors.

iii. Compliance with mandatory disclosure deadlines

This section investigates companies' compliance with Form 8-K filing requirements, to see whether news occurring during CEO absences is released to investors with greater delay than news which occurs when the CEO is in the office. In contrast to most countries that have a "continuous disclosure" regulatory system, the United States permits companies some leeway in releasing material news to the market. The SEC requires companies to file Form 8-K within four business days of a "triggering event," and the official instructions for this form enumerate 36 distinct categories of news for which this requirement applies (a few of these categories require 
filing within two business days).

I use information from the S\&P Filing Dates database, which provides both the event date and filing date for Form 8-K disclosures. The database lists 2,784 filings by the 65 companies during my sample period. When an Form 8-K filing refers to multiple corporate events, I treat the event day as the most recent one covered by the document. If a Form $8-\mathrm{K}$ is filed with the SEC after the stock market closes at 4:00 p.m., I count it as having been filed on the next business day. Of the set of 2,784 observations, 163 relate to company developments that occur on the 3,504 days when CEOs are at their vacation homes, a frequency of $4.7 \%$; the corresponding frequency of material events on all other days is 5.5\%. The drop in frequency of significant corporate events on the CEO's vacation days, about $15 \%$, is much less than the $28 \%$ drop in actual news disclosure frequencies implied by data at the top of the right column in Table 4 (0.096 vs. 0.133). Most of the disclosures on Form 8-K filings occur for three reasons: publication of financial statements, releases of quarterly earnings or other financial news, and the departure of officers or members of the board of directors. These three categories comprise $65 \%$ of the disclosures that are triggered by events while CEOs are at their vacation homes, and $66 \%$ of the disclosures that are triggered on all other days. Among CEOs at their vacation homes and in the office, the data exhibit slight differences among the three categories: quarterly earnings announcements or other material financial news comprise $12 \%$ of the vacation sample and $17 \%$ of the remaining sample, while departures of officers and directors comprise $15 \%$ of the vacation sample and $11 \%$ of the remaining sample ( $p$-values for these differences 0.01 and 0.04 , respectively).

Some basic data about the timeliness of Form 8-K filings indicates that CEO travel 
schedules may impact companies' disclosures. If material events occur when a CEO is at his vacation home, Form $8-\mathrm{K}$ is filed $44.2 \%$ of the time on the same day, but the frequency of sameday filing is higher at $50.4 \%$ if events occur when the $\mathrm{CEO}$ is not at his vacation home.

Similarly, the fraction of Form 8-K filings that miss the four-day deadline is $6.1 \%$ if the events occur while the CEO is at the vacation home, vs. $2.6 \%$ at other times. Both of these differences in means have borderline statistical significance with $p$-values of 0.12 and 0.07 , respectively. ${ }^{9}$

Table 8 presents regression estimates that control for company and month fixed effects, as well as various calendar-related variables such as whether news occurs just prior to a holiday weekend. A Poisson maximum likelihood model shows that CEO vacation trips do not appear to impact the timeliness of Form 8-K filings in a basic model, but if the vacation variable is disaggregated based upon the length of a trip, significant patterns do emerge. If the CEO is on a longer vacation lasting five days or more, the Form $8-\mathrm{K}$ is filed significantly later (these models omit the cases in which Form 8- $\mathrm{K}$ is filed after the four-day regulatory deadline). In contrast, Form 8-K filings occur somewhat quicker than usual if the CEO is on a shorter vacation of 1 or 2 days length. A probit model estimates that the probability of a company missing the four-day filing deadline is significantly greater if events occur when the CEO is on vacation. Disaggregation of the vacation variable by trip length indicates a positive effect at for all estimates, though the effect is somewhat smaller and not statistically significant if the news occurs when the CEO is on a longer trip of at least five work days. Collectively these estimates

\footnotetext{
${ }^{9}$ The fraction of late filings is especially high when financial results are released to investors when CEOs are at their vacation homes: in 4 out of these 36 cases, or $11 \%$, a company announces earnings news to the market but then files the required Form 8-K one week (five business days) or more later. Given that the triggering events for these filings occur due to public announcements already made, the late Forms 8-K in this category probably have little impact on investors. The frequency with which other items occurring during CEO vacations lead to late Form 8-K filings are generally quite close to the overall rate of $6 \%$ exhibited for triggering events during the subsample of vacation days.
} 
are consistent with a conclusion that $\mathrm{CEO}$ vacations tend to lengthen the time taken by companies to release material news to the public.

\section{Implications for investors}

The analysis above suggests two broad implications for a company's shareholders. First, firms' disclosures of news appear to depend significantly upon CEOs' personal travel schedules. When CEOs are away on vacation trips, less news is disclosed and certain regulatory filings are delayed. It is possible that these patterns apply to work-related as well as leisure-related absences, but the paper lacks an identification strategy for differentiating these types of trips. As noted in the literature review section above, companies may expose their investors to adverse financial consequences when the quality of disclosure deteriorates. Firms may face higher costs of capital, less liquidity for their shares, heightened ligitation risk, and ultimately, lower valuation of their securities.

In addition, the analysis suggest the presence of systematic profit opportunities related to CEOs' easily observable travel schedules, since stock prices appear to follow predictable patterns when CEOs leave for vacation and later return. The data collection for this paper suggests that traders could obtain information about CEO trips in real time simply monitoring Internet air traffic websites. By taking a long position in a company's stock for several days after a CEO returns from a trip, an investor could outgain the market indexes by $0.20 \%$ per day, an annualized “alpha" of about $64 \%$ per year. Along with the large daily abnormal returns, investors could speculate on the systematic changes in volatility that appear to occur when a CEO is away on a lengthy trip. To profit from this pattern, a trader would want to sell short derivative securities 
with a high price sensitivity to volatility, or vega, when the CEO's aircraft flies form headquarters to the CEO's vacation home, and then do the opposite when the CEO flies back. With an appropriate portfolio, these strategies could be implemented on a delta-neutral basis, with no sensitivity to the underlying stock price. The tools for these strategies, such as "straddles" and "strangles" involving put and call options, are widely taught to MBA finance students and are easily implemented by traders on the exchanges. See Chaput and Ederington (2005).

Given the ease of observing a CEOs' travel, the existence of these patterns of abnormal returns and volatility seems surprising. The results imply that shareholders do not make the small investments needed to acquire detail about managers' travels or do not recognize the value of the information. One obstacle could undermine investors' ability to track CEO aircraft movements: companies have a right to prevent their aircraft tail numbers from appearing on public Internet sites. Congress passed legislation creating the Block Aircraft Registration Request (BARR) program in 2000 allowing companies to opt out of live tracking sites for security reasons, in order to frustrate potential terrorists or kidnappers. Currently the scope of the BARR program is under reconsideration by the FAA, Congress, and the Obama administration. ${ }^{10}$ However, even if tail numbers were blocked from public Internet sites, they can be matched with company operators either in the FAA's online registry or by making Freedom of Information Act

\footnotetext{
${ }^{10}$ Between 2000 and 2009, the FAA allowed any private aircraft operator to opt out of public tracking databases for an expanded list of reasons including privacy and competitive secrecy, but this policy was reversed in 2009 after the agency was sued by a variety of media outlets seeking complete lists of tail numbers under the Freedom of Information Act. The FAA elected to begin disclosing the identities of operators of aircraft with blocked tail numbers (though not their flight records) in response to such requests in 2009, and a 2010 decision by a federal court rejected a challenge by a business group to the FAA's policy. See Grabell (2010). In August 2011 the FAA greatly reduced its blocking of tail numbers but then reinstated the practice in December 2011, though not retroactively for aircraft that had already been unblocked. See Federal Register vol. 76, no. 242, p. 78328 (December 16, 2011).
} 
requests to the agency. Due to their large size, aircraft can also be observed physically taking off and landing at airports by scouts stationed as "tailspotters," a role played memorably by actor Charlie Sheen in the 1987 feature film Wall Street.

\section{Conclusions}

This paper studies patterns of corporate news disclosures associated with CEOs' personal travel schedules. By merging records of corporate aircraft flights with information about the location of CEOs' vacation residences, I identify days when CEOs are likely to have been away from their offices. I find regularities in stock price behavior consistent CEOs going away right after important news disclosures, and then returning just before subsequent announcements. The CEO's first days back in the office often feature abnormally positive news. When the CEO takes a long vacation trip lasting five work days or more, company stock volatility declines by approximately $13 \%$ for the period he is away. Volatility increases to normal levels in a pattern that begins one day before the CEO returns. Observing the movements of corporate aircraft to and from the CEO's vacation airport could therefore give investors valuable signals about impending disclosures by companies. CEO absences also appear to affect regulatory compliance, as mandatory Form 8-K disclosures of material company news are more likely to occur late if news occurs while CEOs away at their vacation homes.

The results suggest that corporations release news on a schedule determined not only by when information may be important for investors, but also by the constraints of the CEO's personal schedule. However, a variety of tests above support additional hypotheses, suggesting that delays in news announcements also occur simply due to the difficulty of involving a CEO in 
decisions when he is a great distance from headquarters, and also because the CEO directly

produces much of a firm's material news, and such events will inevitably occur less often if the CEO takes time off for vacation. 


\section{References}

Ahern, Kenneth, and Denis Sosyura, forthcoming, "Who writes the news? Corporate press releases during merger negotiations," Journal of Finance

Andersen, Torben G., and Tim Bollerslev, 1997, "Heterogeneous information arrivals and return volatility dynamics: Uncovering the long-run in high frequency returns," Journal of Finance 52, 975-1005.

Bandiera, Oriana, Luigi Guiso, Andrea Prat, and Rafaella Sandun, 2011, "What do CEOs do?" Harvard Business School working paper 11-081.

Bennedsen, Morten, Francisco Pérez-Gonzalez, and Daniel Wolfenzon, 2012, "Estimating the value of the boss: Evidence from CEO hospitalization events," unpublished manuscript, available at gsb.columbia.edu/whoswho/getpub.cfm?pub=5556.

Bushee, Brian J., Joseph Gerakos, and Lian Fen Lee, 2013, "Corporate jets and private meetings with investors," unpublished manuscript, available at ssrn.com/abstract=2141878.

Bushee, Brian J., and Christopher F. Noe, 2000, “Corporate disclosure practices, institutional investors, and stock return volatility," Journal of Accounting Research 38, 171-202.

Chaput, J. Scott, and Louis H. Ederington, 2005, "Volatility trade design,” Journal of Futures Markets 25, 243-279.

Clayton, Matthew C., Jay C. Hartzell, and Joshua Rosenberg, 2005, “The impact of CEO turnover on equity volatility," Journal of Business 78, 1779-1808.

Damodaran, Aswath, 1989, "The weekend effect in information releases: A study of earnings and dividend announcements," Review of Financial Studies 2, 607-623.

Dye, Ronald A., 2010, “Disclosure ‘bunching;” Journal of Accounting Research 48, 489-530.

French, Kenneth R., and Richard Roll, 1986, "Stock return variances: The arrival of information and the reaction of traders," Journal of Financial Economics 17, 5-26.

Grabell, Michael, 2010, "Court upholds release of corporate jets list sought by ProPublica," February 26, available at propublica.org/article/court-upholds-release-of-corporate-jets-list-sought-by-propublica-0226.

Greene, William H., 1998, "Gender economics courses in liberal arts colleges: Further results," Journal of Economic Education 29, 291-300. 
Healy, Paul M., Amy P. Hutton, and Krishna Palepu, 1999, "Stock performance and intermediation changes surrounding sustained increases in disclosure," Contemporary Accounting Research 16, 485-520.

Jiang, Wei, Kai Li, and Wei Wang, 2012, "Hedge funds and Chapter 11," Journal of Finance 67, 513-559.

Kiymaz, Halil, and Hakan Berument, 2003, "The day of the week effect on stock market volatility and volume: International evidence," Review of Financial Economics 12, 363-380.

Koudijs, Peter, 2013, "The boats that did not sail: News, trading and asset price volatility in a natural experiment," unpublished manuscript, available at nber.org/papers/w18831.

Lee, Lian Fen, Michelle Lowry, and Susan Shu, 2013, Investing in connections: Corporate jets and firm value," unpublished manuscript, available at ssrn.com/abstract=2259560.

Leuz, Christian, and Peter Wysocki, 2008, "Economic consequences of financial reporting and disclosure regulation: A review and suggestions for future research," unpublished manuscript, available at ssrn.com/abstract $=1105398$.

Liu, Crocker, and David Yermack, 2012, "Where are the shareholders' mansions? CEOs' home purchases, stock sales, and subsequent company performance" in Sabri Boubaker, Bang Dang Nguyen and Duc Khuong Nguyen eds., Corporate Governance: Recent Developments and New Trends (Heidelberg: Springer-Verlag).

Maremont, Mark, and Tom McGinty, 2011, "For the highest flyers, new scrutiny," The Wall Street Journal, May 21, A1.

McGinty, Tom, and Mark Maremont, 2011, "Nabors draws SEC scrutiny," The Wall Street Journal, November 11.

Naveen, Lalitha, 2006, "Organizational complexity and succession planning," Journal of Financial and Quantitative Analysis 41, 661-683.

Ohlson, James A., and Stephen H. Penman, 1985, "Volatility increases subsequent to stock splits: An empirical aberration," Journal of Financial Economics 14, 251-266.

Patell, James M., and Mark A. Wolfson, 1979, "Anticipated information releases reflected in call option prices," Journal of Accounting and Economics 1, 117-140.

Patell, James M., and Mark A. Wolfson, 1981, "The ex ante and ex post price effects of quarterly earnings announcements reflected in option and stock prices," Journal of Accounting Research 19, 434-458. 
Patell, James M., and Mark A. Wolfson, 1982, "Good news, bad news, and the intraday timing of corporate disclosures," Accounting Review 57, 509-527.

Rajan, Raghuram G., and Julie Wulf, 2006, “Are perks purely managerial excess?” Journal of Financial Economics 79, 1-33.

Sengupta, Partha, 1998, "Corporate disclosure quality and the cost of debt," Accounting Review 73, 459-474.

Skinner, Douglas J., 1997, "Earnings disclosures and stockholder lawsuits," Journal of Accounting and Economics 23, 249-282.

Tsikas, Ilias, 2006, "Periodic stochastic volatility and fat tails," Journal of Financial Econometrics 4, 90-135.

Tsikas, Ilias, 2010, "The economic gains of trading stocks around holidays," Journal of Financial Research 33, 1-26.

Welker, Michael, 1995, "Disclosure policy, information asymmetry, and liquidity in equity markets," Contemporary Accounting Research 11, 801-827.

Yermack, David, 2006, "Flights of fancy: Corporate jets, CEO perquisites, and inferior shareholder returns," Journal of Financial Economics 80, 211-242. 


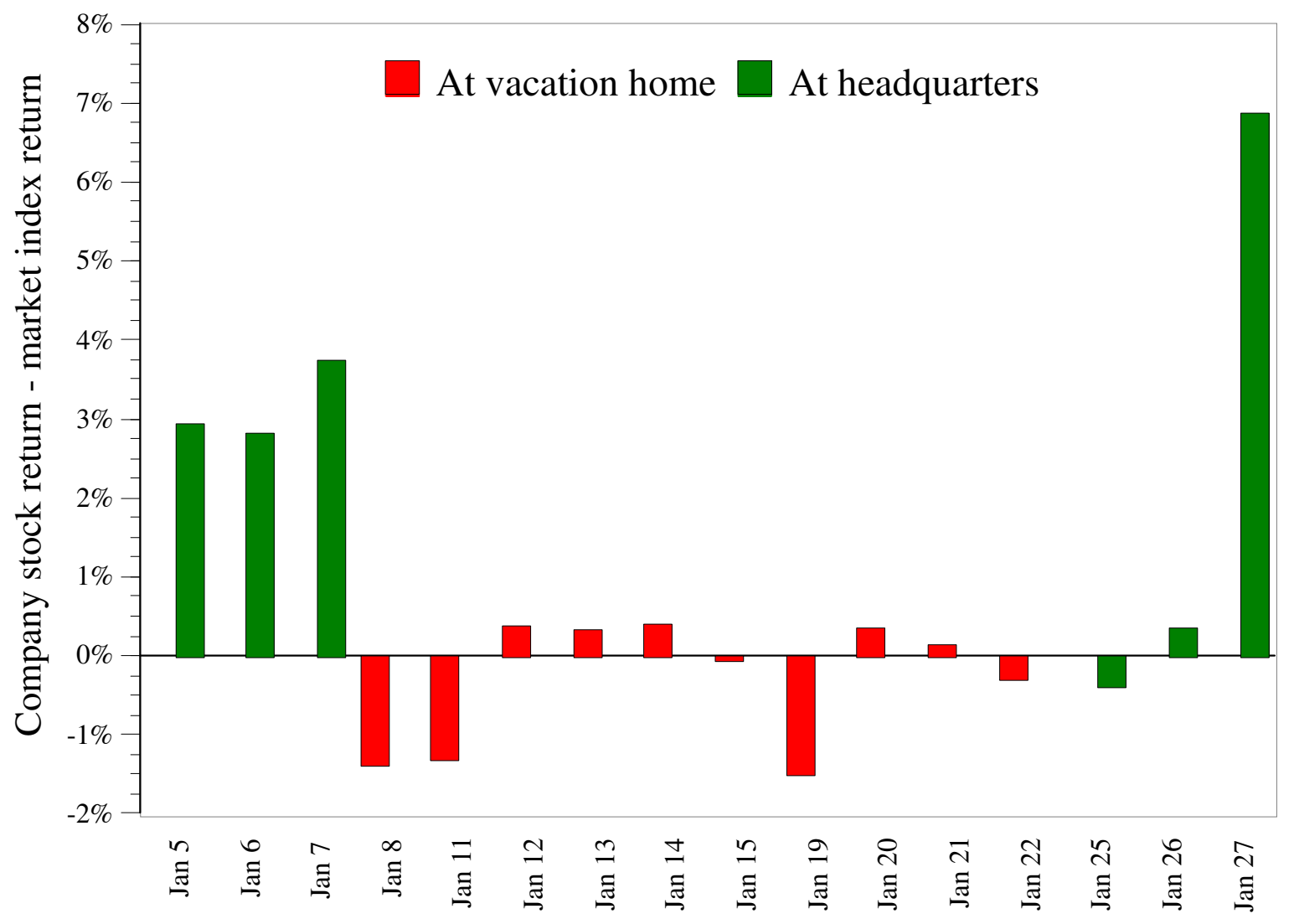

\section{Figure 1}

Boeing Co. daily stock returns, January 2010

The figure shows daily returns for the stock of Boeing Co. minus returns for the CRSP valueweighted market index for an interval of days during January 2010. On January 7 the company announced that its commercial airliner deliveries had increased $28 \%$ for the prior year and also issued an earnings forecast for the year ahead. On January 27 the company announced betterthan-expected earnings results for the $4^{\text {th }}$ quarter of 2009. Little news of significance was announced between those two dates, a period when the company's CEO appears to have been away from headquarters at his vacation home. Flight records for Boeing's Executive Flight Operations unit show that its Bombardier CL-600 corporate jet flew from its headquarters airport near Chicago to Washington, DC on the night of January 7, then from Washington to Palm Beach, FL, at mid-day January 8, returning to headquarters later than afternoon. On January 24, the same aircraft flew from Chicago to Palm Beach and then back to the headquarters airport. Boeing's Chairman and CEO, W. James McNerney Jr., owns a vacation home in Hobe Sound, FL, 34 miles from the Palm Beach airport, according to real estate records. Flight records are obtained from The Wall Street Journal Jet Tracker database. 


\section{Table 1}

\section{Sample of CEOs' trips to their vacation homes}

The table presents descriptive statistics about 66 CEOs' travel to their vacation homes. The timing of trips is based upon flight records of corporate aircraft obtained from The Wall Street Journal Jet Tracker database for the years 2007-2010. To appear in the sample, an executive must be listed as CEO of an S\&P500 firm by ExecuComp during this period, and he must own a vacation property near a destination visited regularly by his company's aircraft. Property ownership is determined from real estate records available on Lexis-Nexis. Data for vacation lengths are based upon weekdays when the U.S. stock market is open for trading and do not include weekends or holidays. A travel day counts as part of a vacation trip if the aircraft takes off from headquarters earlier than 4:00 p.m., or if the return flight lands at the headquarters airport at 12:00 noon or later.

CEOs in sample

Company-day observations (total)

Company-day observations (at vacation home)

Fraction of days spent by CEO at vacation home

Fraction of days spent by CEO at vacation home, by year

Fraction of days spent by CEO at vacation home, by day of week

Monday 


\section{Table 1 \\ continued}

Fraction of days spent by CEO at vacation home, by month

January

$6.7 \%$

February

$7.3 \%$

March

$9.0 \%$

April

$4.9 \%$

May

$3.9 \%$

June

$4.7 \%$

July

$9.9 \%$

August

$9.8 \%$

September

$4.8 \%$

October

$4.3 \%$

November

$6.5 \%$

December

Location of CEOs' vacation homes, by state

Florida

Colorado

10

Massachusetts

South Carolina, New Jersey

Alabama, California, Hawaii, New York, Wyoming

Arizona, Idaho, New Hampshire, North Carolina, Texas, Utah

3 each

2 each

1 each

Length of trips to vacation home

(work days only)

\begin{tabular}{|c|c|}
\hline Fraction of trips & Fraction of total days \\
\hline $37 \%$ & $12 \%$ \\
\hline $23 \%$ & $15 \%$ \\
\hline $12 \%$ & $12 \%$ \\
\hline $8 \%$ & $11 \%$ \\
\hline $19 \%$ & $50 \%$ \\
\hline
\end{tabular}

1 day

$12 \%$

2 days

$12 \%$

3 days

$11 \%$

5 or more days 


\section{Table 2}

\section{Factors associated with CEO vacation days}

The table presents probit regression models with the dependent variable equal to one if the CEO spends a day at his vacation home. The sample includes data for 66 CEOs of S\&P500 companies between 2007 and 2010, with observations included for all weekdays in which the CEO holds his position and the stock market is open. The vacation day indicator equals one for days on which the CEO is out of the office at his vacation home, as determined from a database of corporate aircraft flight records maintained by the Federal Aviation Administration. Data about CEO characteristics is obtained from the ExecuComp database. Total compensation is the TDC1 quantity reported by ExecuComp. Weather data at the location of the CEO's vacation home is obtained from the National Climatic Data Center website. The Ski House indicator variable equals 1 during the October-March period for CEOs who own vacation homes in Colorado, Wyoming, and Idaho. Standard errors robust to serial correlation and heteroskedasticity appear in parentheses below each coefficient estimate. 
Variable

Stock return - market return (prior six months)

CEO age (years)

CEO ownership

Log of CEO total compensation

High daily temperature at headquarters (celsius)

High daily temperature at headquarters squared

Daily precipitation at headquarters (millimeters)

High daily temperature at CEO vacation home (celsius)

High daily temperature at CEO vacation home squared

Daily precipitation at CEO vacation home (millimeters)

High daily temperature at CEO vacation home (celsius) $\mathrm{x}$ Ski House indicator variable

High daily temperature squared

x Ski House indicator variable

Daily precipitation at CEO vacation home (millimeters)

$\mathrm{x}$ Ski House indicator variable

Day prior to holiday (indicator)

Day following holiday (indicator)

Observations

Day of week fixed effects

Calendar month fixed effects

CEO fixed effects

Pseudo $\mathrm{R}^{2}$

Significant at $1 \%$ (a), 5\% (b) and $10 \%$ (c) levels.

\begin{tabular}{|c|c|c|}
\hline Estimate & Estimate & Estimate \\
\hline $\begin{array}{r}0.0692 \\
(0.0477)\end{array}$ & $\begin{array}{r}0.0712 \\
(0.0477)\end{array}$ & $\begin{array}{r}0.0716 \\
(0.0483)\end{array}$ \\
\hline $\begin{array}{c}0.0307^{a} \\
(0.0089)\end{array}$ & $\begin{array}{c}0.0342 \text { a } \\
(0.0088)\end{array}$ & $\begin{array}{c}0.0369 \\
(0.0088)\end{array}$ \\
\hline $\begin{array}{r}-12.7942^{\mathrm{a}} \\
(1.9648)\end{array}$ & $\begin{array}{r}-12.5882^{\mathrm{a}} \\
(1.9600)\end{array}$ & $\begin{array}{r}-12.4752 \\
(1.9762)\end{array}$ \\
\hline \multirow[t]{10}{*}{$\begin{array}{c}-0.1730^{\mathrm{a}} \\
(0.0221)\end{array}$} & $\begin{array}{c}-0.17511^{a} \\
(0.0224)\end{array}$ & $\begin{array}{c}-0.17533^{a} \\
(0.0227)\end{array}$ \\
\hline & $\begin{array}{c}-0.0165^{\text {a }} \\
(0.0030)\end{array}$ & $\begin{array}{c}-0.0170 \\
(0.0030)\end{array}$ \\
\hline & $\begin{array}{c}0.0005^{\text {a }} \\
(0.0001)\end{array}$ & $\begin{array}{c}0.0005 \\
(0.0001)\end{array}$ \\
\hline & $\begin{array}{r}-0.0001 \\
(0.0012)\end{array}$ & $\begin{array}{r}-0.0001 \\
(0.0012)\end{array}$ \\
\hline & $\begin{array}{c}0.0361 \text { a } \\
(0.0047)\end{array}$ & $\begin{array}{c}0.0679 \\
(0.0044)\end{array}$ \\
\hline & $\begin{array}{c}-0.0006^{a} \\
(0.0001)\end{array}$ & $\begin{array}{c}-0.0014 \\
(0.0001)\end{array}$ \\
\hline & $\begin{array}{c}-0.0038^{a} \\
(0.0011)\end{array}$ & $\begin{array}{c}-0.0043 \\
(0.0012)\end{array}$ \\
\hline & & $\begin{array}{c}-0.1066^{a} \\
(0.0083)\end{array}$ \\
\hline & & $\begin{array}{c}0.0041 \\
(0.0004)\end{array}$ \\
\hline & & $\begin{array}{c}0.0313^{a} \\
(0.0073)\end{array}$ \\
\hline $\begin{array}{c}0.6000^{a} \\
(0.0801)\end{array}$ & $\begin{array}{c}0.6266^{\mathrm{a}} \\
(0.0820)\end{array}$ & $\begin{array}{c}0.6094 \\
(0.0814)\end{array}$ \\
\hline $\begin{array}{c}0.7369^{a} \\
(0.0743)\end{array}$ & $\begin{array}{c}0.7681 \text { a } \\
(0.0766)\end{array}$ & $\begin{array}{c}0.7389 \\
(0.0757)\end{array}$ \\
\hline 47,211 & 47,211 & 47,211 \\
\hline Yes & Yes & Yes \\
\hline Yes & Yes & Yes \\
\hline Yes & Yes & Yes \\
\hline 0.1414 & 0.1484 & 0.1564 \\
\hline
\end{tabular}

Yes

Yes
.1564 


\section{Table 3}

\section{Abnormal stock returns}

The table presents Fama-French four-factor models of company stock returns estimated by ordinary least squares. The dependent variable equals the daily stock returns for a sample of 65 companies between 2007 and 2010. The four factors are the return on the market portfolio minus the risk-free rate $(M k t R F)$, the difference in returns for portfolios of growth vs. value stocks $(H M L)$, the difference in returns for portfolios of small vs. large stocks $(S M B)$, and the difference in returns for portfolios of rising minus falling stocks $(U M D)$. All returns are compounded continuously. The vacation day indicator equals one for days on which the CEO is out of the office at his vacation home, as determined from a database of corporate aircraft flight records maintained by the Federal Aviation Administration. Long vacations are those of five work days or longer. The indicator for days prior to long vacation equals 1 for each of the three days preceding a long vacation. The indicator for days following long vacation equals 1 for the second, third, and fourth days after a long vacation ends. Standard errors clustered by company appear in parentheses below each coefficient estimate. 


\begin{tabular}{|c|c|c|c|c|c|}
\hline Variable & Estimate & Estimate & Estimate & Estimate & Estimate \\
\hline Intercept & $\begin{array}{r}0.00004 \\
(0.00006)\end{array}$ & $\begin{array}{r}0.00004 \\
(0.00006)\end{array}$ & $\begin{array}{r}0.00004 \\
(0.00006)\end{array}$ & $\begin{array}{r}0.00001 \\
(0.00006)\end{array}$ & $\begin{array}{r}0.00002 \\
(0.00006)\end{array}$ \\
\hline$M k t R F$ & $\begin{array}{l}1.0294^{\mathrm{a}} \\
(0.0464)\end{array}$ & $\begin{array}{r}1.0294^{\mathrm{a}} \\
(0.0464)\end{array}$ & $\begin{array}{r}1.0294^{\mathrm{a}} \\
(0.0464)\end{array}$ & $\begin{array}{l}1.0294^{\mathrm{a}} \\
(0.0465)\end{array}$ & $\begin{array}{r}1.0295^{\mathrm{a}} \\
(0.0465)\end{array}$ \\
\hline$H M L$ & $\begin{array}{r}0.0196 \\
(0.0775)\end{array}$ & $\begin{array}{r}0.0196 \\
(0.0775)\end{array}$ & $\begin{array}{r}0.0196 \\
(0.0775)\end{array}$ & $\begin{array}{r}0.0195 \\
(0.0775)\end{array}$ & $\begin{array}{r}0.0196 \\
(0.0775)\end{array}$ \\
\hline$S M B$ & $\begin{array}{r}-0.0447 \\
(0.0540)\end{array}$ & $\begin{array}{r}-0.0448 \\
(0.0540)\end{array}$ & $\begin{array}{r}-0.0447 \\
(0.0540)\end{array}$ & $\begin{array}{r}-0.0450 \\
(0.0541)\end{array}$ & $\begin{array}{r}-0.0450 \\
(0.0540)\end{array}$ \\
\hline$U M D$ & $\begin{array}{c}-0.0748^{\mathrm{b}} \\
(0.0366)\end{array}$ & $\begin{array}{c}-0.0748^{b} \\
(0.0366)\end{array}$ & $\begin{array}{c}-0.0748^{b} \\
(0.0366)\end{array}$ & $\begin{array}{c}-0.0745^{\mathrm{b}} \\
(0.0366)\end{array}$ & $\begin{array}{c}-0.0746^{b} \\
(0.0366)\end{array}$ \\
\hline Vacation day indicator & & $\begin{array}{r}-0.0002 \\
(0.0003)\end{array}$ & & & \\
\hline Short vacation indicator & & & $\begin{array}{r}0.0001 \\
(0.0004)\end{array}$ & & $\begin{array}{r}0.0001 \\
(0.0004)\end{array}$ \\
\hline Long vacation indicator & & & $\begin{array}{r}-0.0004 \\
(0.0004)\end{array}$ & & $\begin{array}{r}-0.0004 \\
(0.0004)\end{array}$ \\
\hline Days prior to long vacation & & & & $\begin{array}{l}0.0017^{\mathrm{b}} \\
(0.0008)\end{array}$ & $\begin{array}{l}0.0017^{\mathrm{b}} \\
(0.0008)\end{array}$ \\
\hline Days following long vacation & & & & $\begin{array}{c}0.0020^{\mathrm{a}} \\
(0.0007)\end{array}$ & $\begin{array}{r}0.0020 \\
(0.0007)\end{array}$ \\
\hline $\begin{array}{l}\text { Observations } \\
\mathrm{R}^{2}\end{array}$ & 51,426 & 51,426 & 51,426 & 51,426 & $\begin{array}{l}51,426 \\
04358\end{array}$ \\
\hline $\mathrm{R}^{2}$ & 0.4357 & 0.4357 & 0.4357 & 0.4358 & 0.4358 \\
\hline
\end{tabular}

Significant at $1 \%$ (a), 5\% (b) and 10\% (c) levels. 


\section{Table 4}

\section{Stock volatility and frequency of news announcements for subsamples of trading days}

The table shows realized stock volatility and frequencies of significant news announcements for subsamples of trading days for 65 large companies between 2007 and 2010. CEO vacation schedules are inferred from corporate aircraft flight records maintained by the Federal Aviation Administration. Volatilities are calculated as the standard deviations of continuously compounded daily stock returns, annualized by multiplying by the square root of 252, the number of trading days in a typical year. Dates of news announcements and earnings releases are obtained from the Thomson Reuters Significant Developments database. A long vacation is one lasting five or more work days. A ski trip is one occurring between October and March at a Western ski resort destination. All of the estimated long vacation day volatilities are different from the volatility on the CEOs' days in the office at very low significance levels according to $F$ tests. Similarly, all of the vacation day news frequencies are significantly different from the office day news frequency at very low levels according to $t$-tests.

Subsample

CEO days in office

CEO days at vacation home

CEO days at vacation home

short trips

long trips

long trips including holidays

long trips with no holidays

ski trips

Hawaii trips

Three days before long vacations

Two days before long vacations

Last days before long vacations

First days of long vacations

Middle days

Last days of long vacations

First days back after long vacations

Second days back after long vacations

Third days back after long vacations

\begin{tabular}{|c|c|c|c|}
\hline $\begin{array}{l}\text { Daily } \\
\text { obs. }\end{array}$ & $\begin{array}{l}\text { Annualized } \\
\text { intra-day } \\
\text { volatility }\end{array}$ & $\begin{array}{l}\text { Change in } \\
\text { intra-day } \\
\text { volatility }\end{array}$ & $\begin{array}{c}\text { Significant news } \\
\text { or earnings } \\
\text { frequency }\end{array}$ \\
\hline 47,922 & 0.330 & & 0.133 \\
\hline 3,504 & 0.307 & & 0.096 \\
\hline
\end{tabular}

1,698

0.328

0.110

$1,806 \quad 0.287$

0.083

$902 \quad 0.270$

0.078

$904 \quad 0.304$

0.088

752

0.333

0.069

176

0.310

0.006

206

217

0.302

0.309

$+0.002$

0.102

$217 \quad 0.301$

$+0.006$

0.101

217

0.286

$-0.008$

$-0.015$

0.111

0.092

1,379

0.287

210

0.283

$-0.002$

0.082

$+0.003$

0.081

$210 \quad 0.283$

209

0.292

$+0.000$

0.143

$+0.008$

$+0.013$

0.110

201

0.304

0.109 
Table 5

Stock volatilities for individual companies

The table shows average intra-day stock volatilities for 48 companies on days that the CEOs are on long vacation tripss and days that the CEOs are in the office. A long vacation is defined as a trip to the CEO's vacation home for at least five consecutive working days. Office days are all days excluding both long and short trips to the vacation home. Trips are inferred from flight records of corporate aircraft maintained by the

Federal Aviation Administration. The sample period includes all trading days between 2007 and 2010 for which the individual manager served in the CEO position. Eighteen additional firms are in the sample, but their CEOs do not take any long vacation trips during the sample period. The right column shows the ratio for each company between the average volatilities on office days and long vacation days. Intra-day volatilities are calculated using stock price data based on five-minute trading intervals.

\begin{tabular}{|c|c|c|c|c|c|c|c|c|c|c|c|}
\hline & \multicolumn{2}{|c|}{ Days } & \multicolumn{3}{|c|}{ Volatility } & & \multicolumn{2}{|c|}{ Days } & \multicolumn{3}{|c|}{ Volatility } \\
\hline & Office & Vacation & Office & Vacation & Ratio & & Office & Vacation & Office & Vacation & Ratio \\
\hline General Dynamics & 577 & 5 & 0.281 & 0.132 & 0.468 & Nabors Industries & 816 & 105 & 0.455 & 0.400 & 0.879 \\
\hline Unum Group & 969 & 28 & 0.399 & 0.214 & 0.536 & Mccormick & 237 & 11 & 0.172 & 0.151 & 0.879 \\
\hline Bank of America & 748 & 6 & 0.509 & 0.309 & 0.608 & Starbucks & 712 & 30 & 0.376 & 0.332 & 0.881 \\
\hline Johnson \& Johnson & 979 & 12 & 0.166 & 0.108 & 0.648 & Hess & 932 & 16 & 0.404 & 0.361 & 0.893 \\
\hline Leucadia National & 754 & 103 & 0.382 & 0.253 & 0.661 & Duke Energy & 963 & 28 & 0.232 & 0.210 & 0.908 \\
\hline Yum Brands & 967 & 10 & 0.275 & 0.182 & 0.662 & $\mathrm{VF}$ & 708 & 119 & 0.309 & 0.287 & 0.928 \\
\hline Marathon Oil & 978 & 12 & 0.355 & 0.235 & 0.664 & Covidien & 154 & 48 & 0.209 & 0.196 & 0.939 \\
\hline Abbott Laboratories & 990 & 5 & 0.219 & 0.147 & 0.673 & Anadarko Petroleum & 939 & 75 & 0.402 & 0.386 & 0.960 \\
\hline ConocoPhillips & 992 & 6 & 0.289 & 0.200 & 0.691 & ExxonMobil & 995 & 89 & 0.236 & 0.227 & 0.965 \\
\hline Verizon & 939 & 33 & 0.246 & 0.171 & 0.693 & Amgen Inc & 882 & 29 & 0.249 & 0.241 & 0.967 \\
\hline General Electric & 966 & 15 & 0.315 & 0.243 & 0.772 & Air Products & 663 & 5 & 0.299 & 0.295 & 0.987 \\
\hline Tesoro & 962 & 27 & 0.494 & 0.388 & 0.786 & H.J. Heinz & 824 & 68 & 0.187 & 0.187 & 1.001 \\
\hline Computer Sciences & 115 & 7 & 0.160 & 0.126 & 0.788 & Limited Brands & 961 & 40 & 0.423 & 0.440 & 1.038 \\
\hline W.W. Grainger & 305 & 24 & 0.216 & 0.174 & 0.805 & Boston Scientific & 602 & 15 & 0.385 & 0.426 & 1.107 \\
\hline ConAgra Foods & 948 & 54 & 0.215 & 0.176 & 0.819 & Entergy & 960 & 32 & 0.246 & 0.281 & 1.140 \\
\hline Novellus Systems & 836 & 146 & 0.373 & 0.306 & 0.821 & Johnson Controls & 150 & 6 & 0.214 & 0.247 & 1.154 \\
\hline International Paper & 911 & 47 & 0.407 & 0.347 & 0.851 & Airgas & 889 & 75 & 0.304 & 0.357 & 1.176 \\
\hline EMC & 756 & 103 & 0.338 & 0.288 & 0.853 & Fortune Brands & 205 & 38 & 0.161 & 0.193 & 1.196 \\
\hline Pfizer & 942 & 6 & 0.246 & 0.210 & 0.854 & Ball & 977 & 20 & 0.273 & 0.368 & 1.350 \\
\hline CVS Caremark & 853 & 76 & 0.282 & 0.243 & 0.861 & Procter \& Gamble & 589 & 16 & 0.213 & 0.289 & 1.355 \\
\hline Comcast & 811 & 98 & 0.331 & 0.285 & 0.862 & American International Group & 336 & 24 & 0.264 & 0.424 & 1.606 \\
\hline AK Steel & 966 & 10 & 0.603 & 0.521 & 0.864 & PNC Financial Services Group & 948 & 24 & 0.406 & 0.824 & 2.027 \\
\hline Boeing & 954 & 37 & 0.277 & 0.241 & 0.871 & Lincoln National & 148 & 14 & 0.176 & 0.363 & 2.068 \\
\hline Wyndham Worldwide & 975 & 10 & 0.488 & 0.427 & 0.875 & & & & & & \\
\hline
\end{tabular}




\section{Table 6}

\section{Bivariate probit estimates of CEO vacation days and significant company news days}

The table presents bivariate probit regression estimates in which the probabilities of CEO vacation days and significant company news announcements are modeled jointly. Panel A shows estimates for a bivariate model in which the vacation day indicator appears as an explanatory variable in the news equation, and Panel B shows estimates for a bivariate September 19, 2013 model in which the significant news day indicator appears as an explanatory variable in the vacation equation. The models are identified by using weather variables from the vacation site as instruments for CEO vacation days, and by using the daily change in the company's realized stock volatility as an instrument for significant news announcements. The sample includes data for 66 CEOs of S\&P500 companies between 2007-10, with observations included for all weekdays in which the CEO holds his position and the stock market is open. The vacation day indicator equals one for days on which the CEO is out of the office at his vacation home, as determined from a database of corporate aircraft flight records maintained by the Federal Aviation Administration. The significant news indicator equals one for days on which the company makes a quarterly earnings announcement or releases significant news, according to the Thomson Reuters Significant Developments database. CEO ownership and compensation data is obtained from the ExecuComp database. Weather data is obtained from the National Climatic Data Center website. Realized volatility is calculated using intra-day returns at five-minute intervals. Standard errors robust to serial correlation and heteroskedasticity appear in parentheses below each coefficient estimate. 
Panel A: Significant news days modeled as endogenous to vacations

Intercept

Stock return - market return (prior six months)

CEO age

CEO ownership

Log of CEO total compensation

High temperature at CEO vacation home $\left({ }^{\circ} \mathrm{C}\right)$

High temperature squared

Precipitation at $\mathrm{CEO}$ vacation home $(\mathrm{mm})$

High temperature at $\mathrm{CEO}$ vacation home $\left({ }^{\circ} \mathrm{C}\right) \mathrm{x}$ ski house indicator

High temperature squared $\mathrm{x}$ ski house indicator

Precipitation at CEO vacation home $(\mathrm{mm}) \mathrm{x}$ ski house indicator

High temperature at headquarters $\left({ }^{\circ} \mathrm{C}\right)$

High temperature at headquarters squared

Precipitation at headquarters $(\mathrm{mm})$

Pre-holiday indicator

Post-holiday indicator

Change in realized volatility from previous day

$\mathrm{CEO}$ at vacation home indicator

Observations

Calendar month fixed effects

Day of week fixed effects

CEO fixed effects

$\rho$
CEO vacation day

Coef.
-2.8424
0.1122
0.0195
0.7874
0.0046
0.0747
-0.0020
-0.0032
-0.1064
0.0032
0.0314
-0.0095
0.0001
-0.0007
0.5270
0.6326

Std.Err.

$0.1399^{\mathrm{a}}$

$0.0398^{\mathrm{a}}$

$0.0016^{\mathrm{a}}$

$0.3025^{\mathrm{a}}$

0.0111

$0.0036^{\mathrm{a}}$

$0.0001^{\mathrm{a}}$

$0.0011^{\mathrm{a}}$

$0.0067^{\mathrm{a}}$

$0.0003^{\mathrm{a}}$

$0.0053^{\mathrm{a}}$

$0.0028^{\mathrm{a}}$

0.0001

0.0010

$0.0770^{\mathrm{a}}$

$0.0728^{\mathrm{a}}$
Significant news day

$\frac{\text { Coef. }}{-1.1795} \quad 0.0461^{a}$

$\begin{array}{ll}-0.0069 & 0.0023^{\mathrm{a}}\end{array}$

$-0.0003 \quad 0.0001^{\mathrm{a}}$

$\begin{array}{ll}-0.0005 & 0.0008\end{array}$

$-0.2270 \quad 0.0921^{\mathrm{b}}$

$-0.2540 \quad 0.1061^{\mathrm{b}}$

$0.1609 \quad 0.0426^{\mathrm{a}}$

$-1.0638$

$0.1089^{\mathrm{a}}$
47,117
Yes
Yes
No
$0.5035^{\text {a }}$ 
Panel B: CEO vacation days modeled as endogenous to news

Intercept

Stock return - market return (prior six months)

CEO age

CEO ownership

Log of CEO total compensation

High temperature at CEO vacation home $\left({ }^{\circ} \mathrm{C}\right)$

High temperature squared

Precipitation at $\mathrm{CEO}$ vacation home $(\mathrm{mm})$

High temperature at $\mathrm{CEO}$ vacation home $\left({ }^{\circ} \mathrm{C}\right) \mathrm{x}$ ski house indicator

High temperature squared $\mathrm{x}$ ski house indicator

Precipitation at CEO vacation home $(\mathrm{mm}) \mathrm{x}$ ski house indicator

High temperature at headquarters $\left({ }^{\circ} \mathrm{C}\right)$

High temperature at headquarters squared

Precipitation at headquarters $(\mathrm{mm})$

Pre-holiday indicator

Post-holiday indicator

Change in realized volatility from previous day

Significant news day indicator

Observations

Calendar month fixed effects

Day of week fixed effects

CEO fixed effects

$\rho$

Significant at $1 \%$ (a), 5\% (b) and 10\% (c) levels.
CEO vacation day

$\begin{array}{rc}\text { Coef. } & \underline{\text { Std.Err. }} \\ -3.0783 & 0.1539^{\mathrm{a}} \\ 0.0830 & 0.0416^{\mathrm{b}} \\ 0.0256 & 0.0016^{\mathrm{a}} \\ -0.1893 & 0.3084 \\ 0.0234 & 0.0116^{\mathrm{b}} \\ 0.0768 & 0.0037^{\mathrm{a}} \\ -0.0021 & 0.0001^{\mathrm{a}} \\ -0.0033 & 0.0011^{\mathrm{a}} \\ -0.1121 & 0.0069^{\mathrm{a}} \\ 0.0033 & 0.0003^{\mathrm{a}} \\ 0.0313 & 0.0053^{\mathrm{a}} \\ -0.0088 & 0.0029^{\mathrm{a}} \\ 0.0001 & 0.0001 \\ -0.0007 & 0.0010^{\mathrm{a}} \\ 0.5168 & 0.0874^{\mathrm{a}} \\ 0.6250 & 0.0850^{\mathrm{a}} \\ & \\ -0.1584 & 0.6184 \\ & 47,117 \\ & \text { Yes }^{\text {Yes }} \\ & \text { No } \\ & 0.0180\end{array}$

Significant news day

$-1.3668 \quad 0.0343^{a}$

$-0.0048 \quad 0.0024^{\mathrm{a}}$

$-0.0003 \quad 0.0001^{\mathrm{a}}$

$-0.0003 \quad 0.0008$

$-0.3752 \quad 0.0932^{\mathrm{a}}$

$-0.4570 \quad 0.1062^{\mathrm{a}}$
$0.1725 \quad 0.0441^{\mathrm{a}}$ 


\section{Table 7 \\ Bivariate probit estimates for subsamples of internal and external news days}

The table presents bivariate probit regression estimates in which the probabilities of CEO vacation days and significant company news announcements are modeled jointly. The sample includes data for 66 CEOs of S\&P500 companies between 2007-10, with observations included for all weekdays in which the CEO holds his position and the stock market is open. The vacation day indicator equals one for days on which the CEO is out of the office at his vacation home, as determined from a database of corporate aircraft flight records maintained by the Federal Aviation Administration. The significant news indicator equals one for days on which the company makes a quarterly earnings announcement or releases significant news, according to the Thomson Reuters Significant Developments database. In the left column, the news variable is restricted to announcements that originate within the company, and observations are dropped when news is generated by external sources such as governments, courts of law, plaintiffs' lawyers, ratings agencies, or shareholder activists. In the right column, the news variable equals one when news is generated by these external sources, and observations are dropped for days on which the company announces news generated internally. The models include the full range of independent variables and also the same instrumental variables used in Table 6.

Observations used in estimation

Mean of news indicator variable

Dependent variable: Significant news day

Estimate for CEO vacation variable

Standard error

$\rho$

Dependent variable: CEO vacation day

Estimate for significant news variable

Standard error

$\rho$

Significant at 1\% (a), 5\% (b) and 10\% (c) levels.

\author{
News $=1$ for \\ internal news only
}

46,205

0.111

$-0.9516^{\mathrm{a}}$

(0.1263)

$0.4366^{\mathrm{a}}$

0.4782

(0.5427)

$-0.2946$
News $=1$ for external news only

41,964

0.021

$-0.2368$

(0.3612)

0.0959

$-0.6892$

(1.2019)

0.2772 


\section{Table 8 \\ Timing of Form 8-K filings}

The table presents regression estimates for models of how quickly companies file required Form 8-K disclosures of material news developments with the Securities and Exchange Commission. In most cases companies must file Form $8-\mathrm{K}$ within four business days of a triggering event, and columns 1 and 3 present estimates from Poisson maximum likelihood models of the days elapsed between the event and the filing. Columns 2 and 4 present estimates from probit models in which the dependent variable equals 1 if a company misses the four-day filing deadline. The model includes 2,784 observations for Form 8-K filings by 65 companies between 2007-2010. The Poisson models exclude the 78 cases in which firms did not comply with the four-day filing deadline. Filings made after 4:00 p.m. are counted as having occurred on the next business day. Data are obtained from the S\&P Filing Dates database. Standard errors robust to serial correlation and heteroskedasticity appear in parentheses below each coefficient estimate.

\begin{tabular}{|c|c|c|c|c|}
\hline $\begin{array}{l}\text { Estimation } \\
\text { Dependent variable }\end{array}$ & $\begin{array}{r}\text { Poisson } \\
(1+\text { days })\end{array}$ & $\begin{array}{r}\text { Probit } \\
\text { (late }=1)\end{array}$ & $\begin{array}{r}\text { Poisson } \\
(1+\text { days })\end{array}$ & $\begin{array}{r}\text { Probit } \\
(\text { late }=1)\end{array}$ \\
\hline $\begin{array}{l}\text { Event occurs on a CEO vacation day } \\
\text { (indicator) }\end{array}$ & $\begin{array}{r}0.045 \\
(0.060)\end{array}$ & $\begin{array}{r}0.380^{\mathrm{a}} \\
(0.179)\end{array}$ & & \\
\hline $\begin{array}{l}\text { Event occurs on a CEO vacation day, } \\
\text { during a trip of } 1-2 \text { days (indicator) }\end{array}$ & & & $\begin{array}{l}-0.123^{c} \\
(0.072)\end{array}$ & $\begin{array}{l}0.400^{\mathrm{b}} \\
(0.179)\end{array}$ \\
\hline $\begin{array}{l}\text { Event occurs on a CEO vacation day, } \\
\text { during a trip of } 3-4 \text { days (indicator) }\end{array}$ & & & $\begin{array}{r}-0.009 \\
(0.096)\end{array}$ & $\begin{array}{l}0.527^{b} \\
(0.245)\end{array}$ \\
\hline $\begin{array}{l}\text { Event occurs on a CEO vacation day, } \\
\text { during a trip of } 5+\text { days (indicator) }\end{array}$ & & & $\begin{array}{l}0.308^{\mathrm{a}} \\
(0.097)\end{array}$ & $\begin{array}{r}0.188 \\
(0.307)\end{array}$ \\
\hline $\begin{array}{l}\text { Form } 8-\mathrm{K} \text { is filed on a Friday } \\
\text { (indicator) }\end{array}$ & $\begin{array}{l}0.108^{b} \\
(0.047)\end{array}$ & $\begin{array}{r}-0.073 \\
(0.112)\end{array}$ & $\begin{array}{l}0.107^{\mathrm{b}} \\
(0.047)\end{array}$ & $\begin{array}{l}-0.072 \\
(0.112)\end{array}$ \\
\hline $\begin{array}{l}\text { Event occurs on day prior to holiday } \\
\text { weekend (indicator) }\end{array}$ & $\begin{array}{r}-0.003 \\
(0.083)\end{array}$ & $\begin{array}{c}0.845^{\mathrm{a}} \\
(0.223)\end{array}$ & $\begin{array}{r}-0.004 \\
(0.088)\end{array}$ & $\begin{array}{c}0.847^{\mathrm{a}} \\
(0.219)\end{array}$ \\
\hline Intercept & & $\begin{array}{c}-2.054^{\mathrm{a}} \\
(0.194)\end{array}$ & & $\begin{array}{c}-2.050^{\mathrm{a}} \\
(0.193)\end{array}$ \\
\hline Calendar month fixed effects & Yes & Yes & Yes & Yes \\
\hline Company fixed effects & Yes & No & Yes & No \\
\hline Observations & 2,706 & 2,784 & 2,706 & 2,784 \\
\hline
\end{tabular}

Significant at $1 \%$ (a), $5 \%$ (b) and $10 \%$ (c) levels. 